\title{
DROBNA SZLACHTA W GALICJI - PROBLEM TOŻSAMOŚCI SPOŁECZNEJ
}

\author{
Krzysztof Ślusarek \\ Uniwersytet Jagielloński w Krakowie
}

\section{ABSTRACT \\ MINOR GENTRY IN GALICIA - THE PROBLEM OF SOCIAL IDENTITY}

Research into the social relations in villages where there were noble villages proved that in the $19^{\text {th }}$ century minor gentry was an in-between stratum, which no longer belonged to landed gentry (since they did not own enough property), but at the same time could not be classified as peasants (since they possessed coats of arms). This situation caused numerous new conflicts. For example, in many Galician noble villages there were clashes between the minor gentry and the landed gentry. Landed gentry regarded minor gentry as a quarrelsome and insubordinate element. Many land owners would have gladly treated their poorer fellows as serfs; they would have also been willing to impose on them the obligations of serfdom. Minor gentry, mindful of the danger they faced, wished to distinguish themselves from peasants in every way available. This was a site of very serious conflicts. Given the smallness of their "fortunes," minor gentry did not differ from peasantry in terms of material wealth. However, they tried to distinguish themselves through their customs, their dress, managing style and, above all, the emphasis on the tradition of possessing coats of arms.

Key words: Galicia, minor gentry, peasants, social identity

Słowa kluczowe: Galicja, drobna szlachta, chłopi, tożsamość społeczna

Z austriackich statystyk wojskowych wynika, że w 1824 roku w Galicji mieszkało 31649 dorosłych mężczyzn pochodzenia szlacheckiego ${ }^{1}$. Pozornie liczba ta nie-

1 K. Ślusarek, Drobna szlachta w Galicji 1772-1848, wyd. 2, Jędrzejów-Kraków 2011, s. 42. Zbliżone dane zawierają zestawienia statystyczne za lata 1823-1825, przygotowane na zlecenie lwowskiego Gubernium („Darstellung der politischen Eintheilung der Flächenmaasses, dann des Bau-Bevolkerunges und Viehstandes nach dem Erhebungen des Jahr 1823, 1824, 1825"). Wynika z nich, że w 1823 r. w Galicji było 31662 dorosłych szlachciców, w 1824 r. - 31 656, a w 1825 r. - 31 754. Zob.

Adres do korespondencji: krzysztof.slusarek@uj.edu.pl 
wiele mówi, gdyż odnosi się do dość specyficznej kategorii spisowej, stosowanej w austriackich konskrypcyjnych spisach ludności z przełomu XVIII i XIX wieku. Oznaczała ona ogół mężczyzn, którzy ukończyli 17. rok życia. Używając współczesnego języka, można powiedzieć, że chodziło o mężczyzn w wieku poborowym. Warto przy tym dodać, że ogół dorosłej ludności męskiej dzielono według kryteriów stanowo-zawodowo-demograficzno-wojskowych na: duchownych, szlachtę, urzędników, mieszczan i rzemieślników, chłopów, chałupników, pozostałych (tj. tych, którzy odbyli już służbę wojskową lub zostali z niej zwolnieni) oraz potomstwo męskie (do lat 17). Taka konstrukcja arkuszy spisowych w praktyce uniemożliwia precyzyjne oznaczenie ogólnej liczby szlachty. Można jedynie określić procentowy udział szlachty w ogólnej liczbie dorosłych mężczyzn. Okazuje się, że w 1824 roku nie był on zbyt wysoki i wynosił $3,06 \%{ }^{2}$.

Chociaż konskrypcyjne spisy ludności nie dają możliwości określenia ogólnej liczby szlachty, to jednak mają inną, niezwykle istotną zaletę - pozwalają zbadać rozmieszczenie terytorialne stanu szlacheckiego. Dane liczbowe dotyczące liczebności i struktury ludności podawano bowiem w skali całej Galicji, cyrkułów i poszczególnych miejscowości ${ }^{3}$. Ich naniesienie na mapę dało fenomenalne wyniki, pozwoliło bowiem ustalić, że szlachta nie była rozmieszczona równomiernie na obszarze całej Galicji, lecz koncentrowała się w kilku rejonach zwartego osadnictwa ${ }^{4}$. Największym z nich był rejon podkarpacki, ciągnący się długim pasem Pogórza Karpackiego od Sanoka po granicę z Bukowiną (cyrkuły: sanocki, samborski, stryjski, stanisławowski i kołomyjski). Ponadto drobna szlachta koncentrowała się także w rejonie podolskim, obejmującym cyrkuły: czortkowski, tarnopolski i brzeżański, a także w mniejszych skupiskach w okolicach Lwowa oraz Nowego Sącza, Tarnowa, Bochni i Wadowic (mapa 1). W ponad 700 zaściankach szlacheckich, rozmieszczonych w wyżej wymienionych rejonach, mieszkały wszystkie kategorie drobnej szlachty, a więc: dominikalna, wolna, rustykalna, służbowa oraz miejska.

Przedstawiona tu struktura wewnętrzna drobnej szlachty odbiega nieco od powszechnie stosowanych kategoryzacji. Wynika to z faktu, że klasyfikacja ta powstała na podstawie analizy sytuacji formalno-prawnej drobnej szlachty w Galicji. Dla jasności dalszego wywodu wyjaśnijmy stosowane określenia. Szlachta dominikalna (Antheilbesitzer) posiadała część wsi (tylko jedną) wraz z prawem zwierzchności nad poddanymi (odpowiednik szlachty cząstkowej). Szlachta wolna (Edelleute, kleine Edelleute) miała własne, dziedziczne gospodarstwa i z tego względu była wolna od świadczeń poddańczych na rzecz dworu (odpowiednik szlachty zagrodowej). Szlachta rustykalna użytkowała grunty znajdujące się na obszarze rustykalnym. W jej obrębie wyróżniamy szlachtę czynszową, uprawiającą pańską ziemię w zamian za czynsz

Центральний державний історичний архів України - м. Львів (dalej: ЦДІАУЛ), ф. 146: Namiestnictwo Galicyjskie, оп. 85, спр. 2780, k. 76-79, 80-83, 84-87.

2 K. Ślusarek, Drobna szlachta..., s. 44.

3 Konskrypcyjne spisy ludności z lat 1773-1824 przechowywane są w Archiwum Narodowym w Krakowie w zespole Teki Aleksandra Schneidra (dalej: ANK, Teki Schneidra), sygn. 1800-1858.

${ }^{4}$ Szczegółowo kwestię rozmieszczenia szlachty omówiłem w książce Drobna szlachta..., s. 39-76. W niniejszym szkicu ograniczę się więc jedynie do uwag natury ogólnej. 
pieniężny (Zins-Edelleute), oraz szlachtę zależną (poddańczą), zobowiązaną do świadczeń pańszczyźnianych. Szlachta służbowa i oficjaliści to szlachta utrzymująca się z różnych posad przy dworach ziemiańskich lub drobniejszych posad urzędniczych, a ponadto cała rzesza stale obecnych przy dworach rezydentów i famulusów. Szlachta miejska to szeroko rozumiana kategoria szlachty mieszkającej w granicach administracyjnych miast ${ }^{5}$.

Fenomen drobnej szlachty w Galicji polegał nie tylko na tym, że zamieszkiwała ona na zwartych obszarach osadniczych, przypominających skupiska drobnoszlacheckie na Mazowszu. Ważne jest również to, że w wielu rejonach istniały bardzo duże zaścianki szlachty wolnej oraz równie duże zaścianki szlachty czynszowej. Największe nagromadzenie drobnoszlacheckich gniazd, skąd głównie wywodziły się rody pieczętujące się herbem $\mathrm{Sas}^{6}$, znajdowało się w cyrkułach: samborskim, stryjskim i stanisławowskim. Równie duże skupiska drobnoszlacheckie występowały też jednak w innych rejonach Galicji. Do najludniejszych zaścianków, w których liczba dorosłych szlachciców przekraczała 60, a nierzadko osiągała kilkaset osób, należały: w cyrkule samborskim - Baczyna, Bilina Wielka, Czajkowice, Hołowsko, Hordynia, Horodyszcze, Husne Wyżne, Ilnik, Jawora, Komarniki, Krynica, Kulczyce, Libuchowa, Łąka, Łosiniec, Matków, Mielniczne, Mochnate, Ortyniec, Popiel, Rosochy, Sielec, Stupnica, Terło, Topolnica, Ułyczno i Wysocko Wyżne; w cyrkułach stanisławowskim i kołomyjskim - Bania Berezowska, Bednarów, Berezów Niżny, Berezów Wyżny, Drohomirczany, Dzurków, Grabowiec, Lackie Szlacheckie, Stecowa, Żuraki i Żywaczów; w cyrkułach czortkowskim i tarnopolskim - Brykula, Czabarówka, Dobropole, Iszczków, Kluwince, Kociubince, Kujdanów, Kupczynce, Kurdwanówka, Mogielnica, Polowce, Romanówka, Sopowa, Sosnów, Wasylkowce, Wierzchowce i Zaścienosce; w cyrkule brzeżańskim - Biała, Delejów, Herbutów, Hnilcze, Meducha, Nowosielce, Nowosiółka Koropiecka; w cyrkule sanockim - Dobra i Katyna; w cyrkułach lwowskim i żółkiewskim - Jaśniska i Łozina; w cyrkule stryjskim - Bereżnica Szlachecka, Hołyn, Krechowice, Podmichale, Strutyn Wyżny i Witwica?

5 Więcej na temat kategoryzacji drobnej szlachty zob. ibidem, s. 77-156.

6 Więcej na temat genezy osadnictwa i rozlokowania tych rodów zob. L. Wyrostek, Ród Dragów-Sasów na Węgrzech i Rusi Halickiej, „Roczniki Towarzystwa Heraldycznego” 1931-1932, t. 11, s. $1-152$.

Niektóre z zaścianków mają monografie w języku polskim. Zob. m.in. P. Dąbkowski, Szlachta zaściankowa w Korczynie i Kruszelnicy nad Stryjem, Lwów 1936; K. Ślusarek, Bilina Wielka, Kraków 2010. W ostatnim czasie pojawia się sporo monografii galicyjskich miejscowości wychodzących spod pióra ukraińskich autorów. W znacznej części powielają one jednak ustalenia polskiej historiografii przedwojennej (zob. m.in. С. Сородник, Історія корчинської шляхти. Минуле і сучасне села Корчин, Львів 2002; Історія села Кульчиць і роду Драго-Сасів, ред. Я. Радевич-Винницький, [Львів] 1995). Autorzy, którzy z kolei sięgali do źródeł archiwalnych, z rzadka dostrzegają istnienie zaścianków szlacheckich w opisywanych miejscowościach (zob. m.in. В. Лаба, Історія села Ільник від найдавніших часів до 1939 року, Львів 2009). 


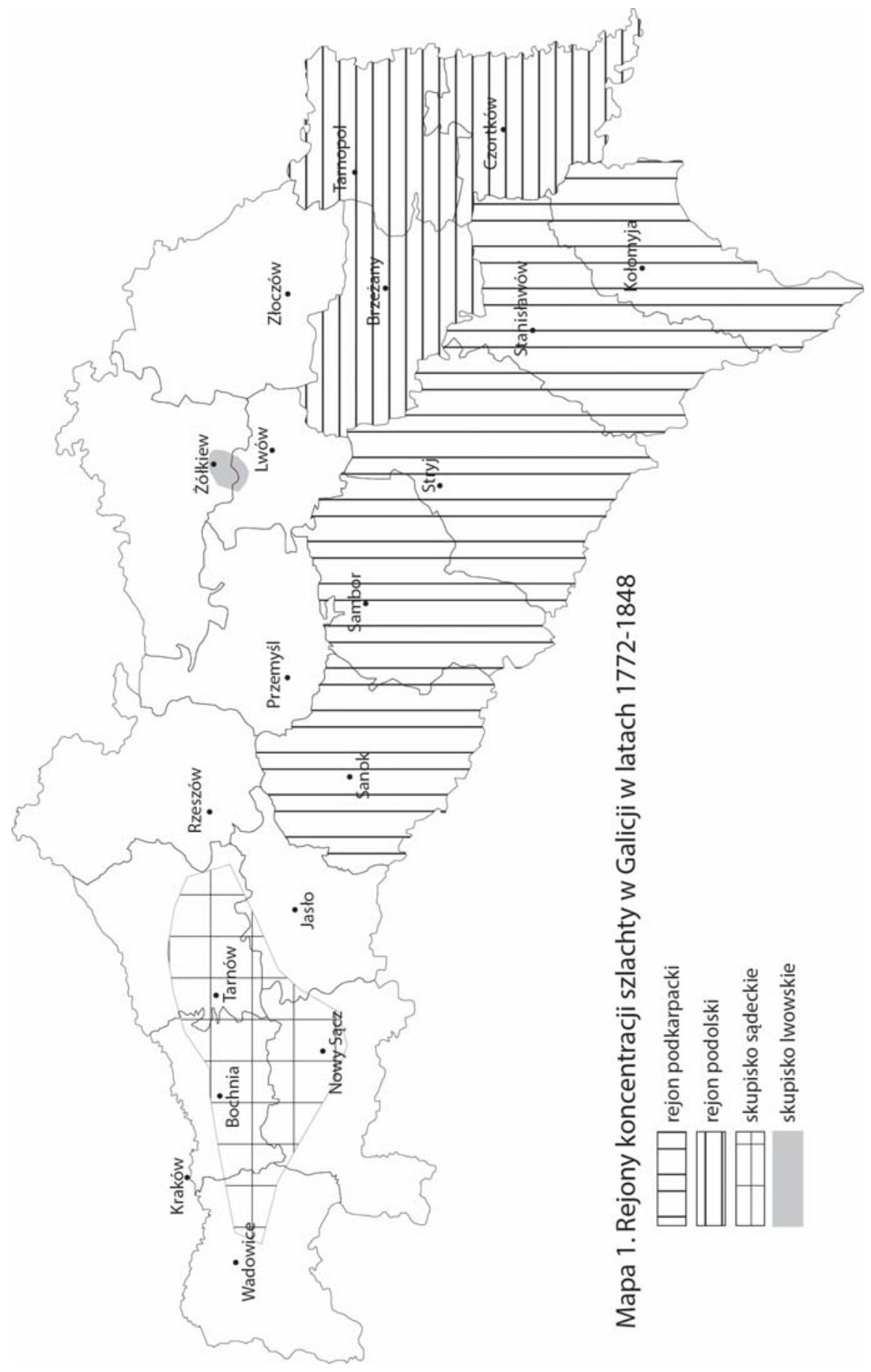


W tym miejscu należy jeszcze dodać, że o specyfice drobnej szlachty galicyjskiej świadczyło także to, że zaścianki były rozlokowane w różnych typach własności. Na przykład gniazda szlachty wolnej w rejonie podkarpackim znajdowały się głównie na obszarze dóbr kameralnych (dawnych królewszczyzn). Mieszkająca w nich szlachta posiadała dziedziczne gospodarstwa, ale najczęściej miały one o wiele mniejszą powierzchnię od znajdujących się $\mathrm{w}$ tej samej wsi gospodarstw chłopskich. W rejonie podolskim zaścianki znajdowały się najczęściej w dużych kompleksach majątkowych należących do galicyjskich ziemian. Osadzona w nich szlachta czynszowa w zamian za czynsz uprawiała gospodarstwa równe chłopskim zagrodom. Były też wsie, w których obok folwarku znajdowały się pomniejsze cząstki szlacheckie.

Taka struktura własności (w rejonach, gdzie występowała drobna szlachta) powodowała, że na wsi egzystowały obok siebie trzy społeczności (nie licząc Żydów): ziemianie, drobna szlachta i chłopi. I tu nasuwa się pytanie o tożsamość społeczną szlacheckiego drobiazgu, czyli o przynależność do stanu szlacheckiego w sensie formalnym (dostęp do przywilejów) i faktycznym (akceptacja przez współbraci) oraz związane z tym relacje z ziemiaństwem i chłopami.

Wyjaśnienie kwestii formalnej przynależności do stanu szlacheckiego nie nastręcza trudności. Przede wszystkim należy zauważyć, że z formalnoprawnego punktu widzenia drobna szlachta mogła korzystać z praw szlacheckich, o ile tylko potrafiła spełnić warunki dające do nich dostęp ${ }^{8}$. W praktyce $\mathrm{z}$ większości uznawanych przez austriackiego zaborcę przywilejów stanowych (dostępu do urzędów, odrębnego sądownictwa, Tabuli Krajowej, prawa do zwierzchności gruntowej nad poddanymi) korzystać mogły - choć w różnym zakresie - zamożniejsze grupy drobnej szlachty: dominikalna i wolna. W przypadku szlachty rustykalnej trudno natomiast mówić, by mogła ona na przykład dochodzić swych praw przed sądem szlacheckim czy piastować różne urzędy. W tym miejscu należy jednak zaznaczyć, że kwestia formalnoprawnej przynależności do stanu szlacheckiego miała istotne znaczenie w drugiej połowie XVIII i w pierwszych dekadach XIX wieku. Później rola tego czynnika stopniowo malała, a po wprowadzeniu reform ustrojowych z lat 40.-60. XIX wieku (były to: uwłaszczenie chłopów, reforma sądownictwa i administracji oraz oparcie praw wyborczych do organów autonomicznych na cenzusie majątkowym) całkowicie stracił on na znaczeniu.

Inaczej rzecz przedstawia się z faktyczną przynależnością do stanu uprzywilejowanego. Tutaj z całą stanowczością należy stwierdzić, że drobna szlachta, niezależnie od kondycji materialnej, zawsze uważała się za część stanu szlacheckiego. Problem wszakże polegał na tym, czy inni członkowie wiejskiej społeczności myśleli tak samo. Chodzi tu szczególnie o dwie grupy społeczne: ziemiaństwo, z którym drobiazg szlachecki miał wspólne stanowe korzenie, oraz chłopów, od których nie odróżniał się położeniem materialnym.

Jak wynika z materiałów źródłowych, ziemiaństwo zajmowało nieprzychylne stanowisko wobec swych biedniejszych współbraci. Przede wszystkim właściciele ziemscy

8 Problematyka ta została szerzej omówiona w dwóch moich pracach: Drobna szlachta..., s. 157176; Austria wobec polskiej szlachty z Galicji w latach 1772-1861, „Studia Historyczne” 2012, t. 55, z. 2, s. $185-200$. 
starali się manifestować swoją wyższość wobec drobnej szlachty. Dla bogatej szlachty biedny, nieposiadający ziemi „szaraczek” - jeśli nie mógł się stać poplecznikiem głosującym na sejmiku zgodnie z wolą swego opiekuna - już nie mógł być kompanem. Zaborca austriacki zniósł bowiem sejmiki, a czasy równości szlacheckiej dawno minęły.

Mówimy tu o dostrzegalnym w warunkach porozbiorowych dystansie - lub w najlepszym razie obojętności - w relacjach sąsiedzkich i towarzyskich. Trudno jednak było zachować taką postawę w sytuacji, gdy zagrody drobnoszlacheckie sąsiadowały z ziemiańskimi folwarkami. Wtedy najczęściej dochodziło do konfliktów. Miały one różne podłoże, ale zwykle chodziło o powiększenie majątku. Zamożny szlachcic, który niejednokrotnie wywodził się z tego samego lub sąsiedniego zaścianka, starał się powiększyć swój majątek kosztem niezamożnych współbraci. Mechanizm działania w takich wypadkach był podobny: biedniejszy szlachcic, nie mogąc utrzymać rodziny lub sprostać obciążeniom podatkowym, pożyczał od bogatszego sąsiada pieniądze pod zastaw małych kawałków ziemi lub sprzedawał przysłowiowe „fortuny”. W takiej sytuacji ów „szaraczek” działał świadomie i godził się na uszczuplenie rodowego majątku. Zdarzały się jednak przypadki - i to wcale nieodosobnione - że inicjatywa leżała po stronie zamożniejszego sąsiada, który wszelkimi dostępnymi metodami, w tym również przemocą, dążył do powiększenia swojej posiadłości. W takich wypadkach dochodziło do bardzo drastycznych i długotrwałych konfliktów. Szlachta zagrodowa, czując się zagrożona w swoim posiadaniu, broniła się przed tą agresją wszelkimi dostępnymi środkami. Na porządku dziennym były wtedy wzajemne oskarżenia o szkody wyrządzane na polach, o zaoranie „dwóch skib” czy wypasanie bydła na polach'. Bogatszy szlachcic często posuwał się natomiast do przemocy, organizując między innymi zbrojne zajazdy.

Jako przykład tego typu konfliktów można przywołać długotrwały spór między rodzinami Baczyńskich i Sozańskich. Baczyńscy, pieczętujący się herbem Sas, mieszkali w leżącej na lewym brzegu Dniestru wsi Baczyna w cyrkule samborskim ${ }^{10}$. Na przeciwległym brzegu Dniestru leżała wieś Sozań, w której oprócz gospodarstw szlachty wolnej sporą cząstkę posiadała rodzina Sozańskich. Konflikt między Baczyńskimi a rodziną Sozańskich rozpoczął się w latach 90. XVIII wieku. Jak wynika z materiałów źródłowych, uboga szlachta baczyńska nie była w stanie opłacać podatków, nie mówiąc już o utrzymaniu rodzin. Fakt ten starał się wykorzystać Michał Sozański, właściciel części Sozani, który wykupił kilka mniejszych działek w Baczynie, a następnie zaczął przejmować niektóre grunty należące do całej gminy szlacheckiej. Zgromadziwszy w swych rękach największą cząstkę w Baczynie, uzyskał prawa dominialne, zbudował we wsi pierwszą karczmę, przejmując tym sposobem prawo propinacji, zabronił miejscowej szlachcie połowu ryb w Dniestrze, a także zajął niektóre działki należące do szlachty ${ }^{11}$.

9 Przykładów takich konfliktów jest wiele. Zob. m.in. ANK, Teki Schneidra, sygn. 28, 682, 888, 1038, 1071, 1608. Zob. także: Ł. Jewuła, T. Kargol, K. Ślusarek, Dwór, wieś i plebania w przestrzeni społecznej zachodniej Małopolski w latach 1772-1815, Kraków 2015.

$10 \mathrm{~W}$ tym miejscu warto nadmienić, że w Baczynie mieszkała wyłącznie szlachta, chłopów nie było tam w ogóle.

${ }_{11}$ Z notatki A. Schneidra wynika, że przypadek szlachty baczyńskiej stał się tłem powieści Walerego Łozińskiego pt. Szlachcic chodaczkowy. Zob. ANK, Teki Schneira, sygn. 28, nlb. 
Działania te wywołały sprzeciw mieszkańców zaścianka i doszło do wieloletniego sporu. Pierwsze czynności prawne podjęto w 1796 roku. Rok później urząd cyrkularny w Samborze przeprowadził wizję lokalną szkód, jakie w lesie należącym do M. Sozańskiego miał wyrządzić jeden z mieszkańców Baczyny - Tomasz Kotłowicz Baczyński. W 1798 roku cała gmina szlachecka w Baczynie oskarżyła z kolei Sozańskiego, zarzucając mu między innymi, że bezprawnie zabronił połowu ryb w Dniestrze, zajął niektóre grunty oraz zniszczył uprawy i sprzęty gospodarskie. Później obie strony konfliktu wzajemne oskarżały się o zajęcie ziemi, niszczenie upraw i zbrojne najścia. Jeśli władze administracyjne wydały jakąś decyzję, strona, która nie zgadzała się z orzeczeniem, pisała odwołania. Doszło nawet do tego, że w 1806 roku sprawa trafiła do Kancelarii Nadwornej i cesarza Franciszka I ${ }^{12}$. Nie przyniosło to jednak rozstrzygnięcia.

W 1815 roku konflikt wszedł w nową fazę - tym razem Tomasz i Marianna Kotłowiczowie Baczyńscy, a później Aleksander Kotłowicz Baczyński pozwali przed lwowskie Forum Nobilium Adama Sozańskiego, syna i spadkobiercę wspomnianego wyżej Michała, domagając się zwrotu czwartej części roli o nazwie Kropiwniszczyzna $^{13}$. W 1817 roku sąd wydał wyrok, nakazując Adamowi Sozańskiemu zwrot spornego gruntu oraz wypłacenie odszkodowania za bezprawne używanie. Od tego wyroku Sozański jednak się odwołał. Skutek był taki, że w 1818 roku Trybunał Apelacyjny we Lwowie uchylił wyrok Forum Nobilium ${ }^{14}$. Dalszy bieg sprawy nie jest znany, ale wiadomo, że w 1840 roku ponownie wróciła ona do Forum Nobilium. Wówczas to przesłuchano kilku świadków mających potwierdzić prawa Baczyńskich do części Kropiwniszczyzny. Przy tej okazji ujawnione zostały zdarzenia sprzed blisko 50 lat, które rzuciły nowe światło na sprawę. Jeden ze świadków, 75-letni Jan Leszkowicz Tereszko Baczyński, zeznał, co następuje:

Będzie temu lat 50, gdy śp. Michał Sozański wpadłszy z ludźmi w dość dużej ilości i z furami ze wsi Czepel na pola do Tomasza i Marianny Kotłowiczów Baczyńskich należne i przez nich używane - i zboże tamże w półkopkach znajdujące się zabierać i do Sozani zawieźć kazał.

Byłem naocznym tego świadkiem, jak ludzie P. Michała Sozańskiego w czasie tego napadu zboże różnego gatunku Kotłowiczów Baczyńskich własne, jako i ogrodowiznę, pozabierali, a płoty, któremi osiadek [tu: domostwo - K.Ś.] Tomasza Kotłowicza Baczyńskiego był ogrodzony, porozrywali, a na którym to osiadku teraz folwark P. Adama Sozańskiego znajduje się.

Widziałem na własne oczy, jak przy tym napadzie Tomasz i Marianna Kotłowicze Baczyńscy wzbraniali się zabierać im zboża ich własnego z pól, przez nich używanych i posiadanych, różnego gatunku, ale będąc bitemi, przemocy ulec musieli. Widziałem, i to na własne oczy, jak tegoż samego roku, ale nieco później, zabierali ludzie Pana Michała Sozańskiego kapustę z pola w miejscu pod Wisznikami zwanym - małżonków Kotłowiczów własną, a gdy Marianna Kotłowiczowa Baczyńska zabieraniu temu opierała się, dworzanin P. Michała Sozańskiego, niejaki Mehalicki, bijąc ją - korale na szyi jej rozerwał ${ }^{15}$.

12 ANK, Teki Schneira, sygn. 28, nlb.

13 ЦДІАУЛ, ф. 149: Forum Nobilium we Lwowie, оп. 4, спр. 2327, k. 2-5.

14 Ibidem, спр. 2328, k. 3-8.

15 Ibidem, спр. 2327, k. 13. 
Ostatecznie w 1841 roku sąd uznał wiarygodność świadków oraz autentyczność przedłożonych dokumentów i nakazał A. Sozańskiemu zwrócenie bezprawnie zajętego gruntu. Od powyższej decyzji Sozański odwołał się ponownie, lecz Trybunał Apelacyjny utrzymał wyrok pierwszej instancji ${ }^{16}$.

Okazuje się jednak, że konflikt między Baczyńskimi i Sozańskimi wcale się nie zakończył, a nawet przeciągnął się na trzecie pokolenie. Świadczy o tym zapis, jaki znalazł się w kontrakcie kupna-sprzedaży części wsi Baczyna, zawartym w 1865 roku pomiędzy Antonim Sozańskim, synem Adama i wnukiem Michała Sozańskiego, a Maciejem Štreciem:

Dworskie pola wsi Sozani, położone nad Dniestrem, są przez tę rzekę łupane i szutrem zasypywane, przez co uformowała się przestrzeń, czyli Ryń, leżąca między austerią, zwaną Wychadowowka, a Górą Baczyńską. O część tej Ryni jest spór prowizjonalny między szlachtą baczyńską a Antonim Sozańskim. Kupujący Maciej Štreć obowiązuje się żadnego udziału w tym sporze nie brać i uznaje całą Ryń [za] własność W. Antoniego Sozańskiego ${ }^{17}$.

Konflikty zdarzały się nie tylko między szlachtą wolną a ziemiaństwem, lecz także między posesorami majątków a szlachtą czynszową. W tym wypadku spory były jeszcze ostrzejsze. Wynikało to z faktu, że zwierzchność gruntowa z reguły ledwo tolerowała szlachtę czynszową. Mało tego, uważała ją za ludność bezpodstawnie uprzywilejowaną, przy tym bardzo zuchwałą, sprawiającą wiele kłopotów i przynoszącą dziedzicowi same straty. Doskonałym przykładem jest tu konflikt między szlachtą czynszową mieszkającą w Obertynie ${ }^{18}$ a dziedzicem tego miasteczka hrabią Janem Skarbkiem. W 1785 roku pełnomocnik dziedzica Jan Żórawski skierował do urzędu cyrkularnego w Stanisławowie notę o następującej treści:

Każdemu z dziedziców w dobrach swoich podług własnego pomysłu intratę powiększyć jest wolno, arendowany zaś, czyli wyraźniej mówiąc, czynszowy szlachcic, tego podatku ledwie część trzecią daje, ile chłop z podobnego gruntu kalkulując czyni. Do tego rzeczeni szlachta ustawicznie z chłopami o spasanie sianożęci [tu: łąk - K.Ś.] i zboża kłócą się i w tej mierze jurysdykcji dworskiej uprzykrzają się, dla załatwienia których kłótni umyślnie państwo [tu: dominium - K.Ś.] oficjalistę kilkaset złotych kosztującego trzymać musi. Taż jednak szlachta przez wygórowanie swojej zuchwałości powodować się [tu: podporządkować - K.Ś.] jurysdykcji nie chce, tylko domaga się, żeby ich jako szlachtę do trybunału pozywać. Są tudzież najwyższe rozporządzenia, by od robienia 12 dni szarwarków nikt wolnym nie był, i te szarwarki do reparacji dróg publicznych, sadzenia drzew przy traktach, do młynów, mostów, grobel etc. obracane być powinny; a i tych tutejsza szlachta odbywać wzbrania się, więc dominium u prześwietnej doprasza się komisji szlachtę ową nieposłuszną do odrabiania 12 dni szarwarków [...] ponaglić rozkazem i nakazać, żeby zawsze bez żadnej sprzeczki [...] wychodzili i odrobili ${ }^{19}$.

16 Ibidem, спр. 2329, k. 5-10.

17 ANK, Teki Schneidra, sygn. 28, nlb.

18 Więcej na temat zaścianka w Obertynie zob. K. Ślus arek, Drobna szlachta w Obertynie. Studium $z$ dziejów szlachty w matym miasteczku na przełomie XVIII i XIX wieku, „Studia Historyczne” 1994, t. 37, z. 3, s. 359-374.

19 ANK, Teki Schneidra, sygn. 1166, nlb. 
Wydźwięk cytowanego dokumentu jest jednoznaczny: dominium chciało traktować szlachtę czynszową na równi z chłopami, dlatego nie uznawało jej szlacheckich praw. Cenzyci nie byli jednak łatwym przeciwnikiem i potrafili się bronić przed zakusami dworu. Dowodzi tego kolejny konflikt z udziałem szlachty obertyńskiej. Otóż w 1810 roku złożyła ona skargę na działalność mandatariusza z dominium obertyńskiego Józefa Dwernickiego. Zdaniem mieszkańców zaścianka Dwernicki miał między innymi rozdać sporne grunty okolicznym chłopom, choć szlacheccy gospodarze już zdążyli je obsiać jarym zbożem:

Józef Dwernicki, mandatariusz, zasiewy zabrawszy szlacheckie, poddanym porozdawał; a szlachcie niemałe czyni przykrości, którymi już niektórych z Obertyna powyganiał, i tych, którzy są dręczonymi egzekutorami, wymyślając różne przykrości. Dość na tym, że tak szlachta uciśniona nie mają najmniejszego do życia sposobu ${ }^{20}$.

Szlachta żądała przysłania do Obertyna komisji, która na miejscu zbadałaby sytuację. Spór ciągnął się jeszcze przez wiele lat. W 1823 roku, kiedy nowym właścicielem Obertyna był hrabia Józef Kalinowski, sprawa trafiła nawet do Gubernium. Ostateczne rozwiązanie przyniosła jednak dopiero reforma uwłaszczeniowa. W jej rezultacie szlachta czynszowa, podobnie jak chłopi, stała się właścicielem uprawianych gruntów ${ }^{21}$.

Bardzo często powodem sporów szlachty czynszowej z dominiami była wysokość czynszów. Cenzyci uważali, że płacone przez nich daniny były bardzo wygórowane, dlatego żądali ich obniżenia. Gdy zabiegi te okazywały się nieskuteczne, odwoływali się do cyrkułów, a nawet do lwowskiego Gubernium ${ }^{22}$. Tymczasem dominia z reguły wyrażały pogląd przeciwny, o czym świadczy przywoływany wyżej przykład z Obertyna. Mało tego, zwierzchność dworska usiłowała egzekwować od cenzytów także i inne powinności, na przykład szarwarki. Pojawiały się również próby usunięcia szlachty czynszowej z zajmowanych gospodarstw ${ }^{23}$.

Ciągle powtarzające się konflikty i spory powodowały, że właściciele ziemscy, dzierżawcy lub działający w ich imieniu dworscy urzędnicy wnosili skargi do władz cyrkułowych. Żalili się w nich, że ich biedniejsi współbracia zajmują grunty należące do chłopów, wyrządzają szkody na polach, a przede wszystkim są niepokorni, niechętnie podporządkowują się zwierzchności dworskiej. W tym duchu w 1803 roku skargę napisał Aleksander Żelisławski, posesor dominium w Sielcu w cyrkule samborskim: „Szlachta w Sielcu mieszkająca w żadnym punkcie [...] najwyższym przepisom, publicznym nakazom, jako i porządkom [tu: zarządzeniom - K.Ś.] dominium nie jest posłuszna" ${ }^{24}$.

Wcale nierzadkie były też donosy. Na przykład urzędnik skarbowy ze Stanisławowa Franciszek Siarkiewicz, prosząc o zachowanie anonimowości, zadenuncjował

20 ЦДІАУЛ, ф. 146, оп. 87, спр. 206, k. 13.

21 Ibidem, k. 46-52, 90-91.

22 Jako przykład można podać spór szlachty z Hnilcz w cyrkule brzeżańskim. Zob. ANK, Teki Schneidra, sygn. 1616, nlb.; Львівська національна наукова бібліотека України імені В. Стефаника, Zbiór Czołowskiego, sygn. 941/III, nlb.

23 ANK, Teki Schneidra, sygn. 1166 i 1449, nlb.

24 Ibidem, sygn. 1449, nlb. 
kilkunastu szlachciców z zaścianka w Berezowie w cyrkule kołomyjskim, że ci zajęli i od kilku lat bezprawnie użytkowali grunty kameralne:

Szlachta dzielnice [tu: cząstki - K.Ś.] w tymże Berezowie i Bańkach Berezowskich [tu: w Bani Berezowskiej - K.Ś.] posiadając, w czasie pomiarów urbarialnych z gruntów niegdyś J.W. Cetnera i J.W. Teodora Potockiego, starosty olsztyńskiego, do dóbr nadwórniańskich należących, a teraz kameralnych, do swoich przywłaszczywszy, dotąd nieodpłatnie wszyscy używają ${ }^{25}$.

Z przytoczonych wyżej przykładów jasno wynika, że zarówno władze administracyjne, jak i ziemianie mieli nad wyraz niechętny stosunek do drobnej szlachty. Mało tego, można zauważyć, że biedoty szlacheckiej nie uznawano już za pełnoprawnych członków stanu. Pod koniec XVIII i w pierwszej połowie XIX wieku szlachtę nieposiadającą poddanych i własnoręcznie uprawiającą ziemię (obojętnie: dziedziczną czy dzierżawioną) chętniej umieszczano wśród poddanych zobowiązanych do pańszczyzny niż wśród uprzywilejowanego stanu szlacheckiego. Zmiana nastawienia ziemiaństwa i administracji bez wątpienia świadczy o tym, że pozycja społeczna drobnej szlachty uległa zmianie.

Pozbawiona części praw szlacheckich, porównywana do chłopów i nietolerowana przez sporą część ziemiaństwa drobna szlachta zachowała jednak wiele cech świadczących o przynależności do stanu uprzywilejowanego. Przede wszystkim niektórzy członkowie tej społeczności mieli udokumentowane szlachectwo. Zauważył to nawet namiestnik Galicji hrabia Agenor Gołuchowski, który w 1857 roku przekazał mieszkańcom zaścianka we wspomnianym wyżej Berezowie egzemplarz świeżo wydanego Pocztu szlachty galicyjskiej i bukowińskiej ${ }^{26}$. Ekspediujący przesyłkę sekretarz Wydziału Stanów January Skarżyński w liście napisanym w imieniu Gołuchowskiego podnosił zasługi przodków szlachty berezowskiej:

Ich dziadowie nabytego zasługami odległych przodków szlachectwa godnymi się okazywali niezłomną wiernością dla prawowitych monarchów, tudzież stałą gotowością do ponoszenia ciężarów i pełnienia posług publicznych, poczytując to sobie za obowiązek należeć do pierwszych, gdzie tylko chodziło o przyczynienie się do dobra pospolitego; mieli bowiem to na własnym doświadczeniu oparte przekonanie, że od ogólnego dobra nieodłączne jest dobro osobiste i pomyślność ich zagród szlacheckich ${ }^{27}$.

Przesyłkę zaopatrzoną w cytowany list trudno uznać jedynie za przejaw kurtuazji, gdyż adresowany był do mieszkańców jednego z najludniejszych zaścianków szlacheckich w Galicji ${ }^{28}$.

Wydaje się, że bardzo duże znaczenie dla zachowania odrębności i podkreślenia związku ze stanem szlacheckim miał fakt, że w XIX stuleciu zachowały się jeszcze odrębne, właściwe tylko dla drobnej szlachty instytucje zwyczajowe. Przykładem tego

25 Ibidem, sygn. 80, nlb.

26 Poczet szlachty galicyjskiej i bukowińskiej, Lwów 1857. W istocie był to wykaz szlachty wylegitymowanej w Galicji.

27 ANK, Teki Schneidra, sygn. 80, nlb.

28 Według danych z 1824 r. w Berezowie Niżnym mieszkało 301 dorosłych szlachciców, w Berezowie Wyżnym - 729, a w Bani Berezowskiej - 98. Wszystkie te trzy miejscowości sąsiadowały ze sobą. Mieszkało w nich łącznie 3151 osób. Zob. K. Ślu sarek, Drobna szlachta..., s. 197-198. 
typu instytucji były gminy szlacheckie, istniejące w niektórych zaściankach, zwłaszcza tych rozlokowanych w dobrach kameralnych (dawnych królewszczyznach). Instytucje te działały w co najmniej kilkudziesięciu miejscowościach, między innymi w Baczynie, Berezowie Niżnym i Wyżnym, Bilinie Wielkiej, Komarnikach, Sielcu, Jaworej, Katynie, Krynicy, Kulczycach, Libuchowej, Łące, Terle, Tustanowicach. Początków gmin szlacheckich należy się doszukiwać jeszcze w XVI wieku, kiedy szlachta organizowała się w gminy, głównie w celach obronnych. W wiekach następnych gmina funkcji obronnych już nie spełniała, lecz przekształciła się w instytucję quasi-samorządową: organizowała życie zaścianka, dbała o przestrzeganie porządku i prawa, a niekiedy odgrywała rolę urzędu uwierzytelniającego czynności prawne ${ }^{29}$. Na czele gminy stał przełożony, częściej zwany wójtem lub prefektem, którym zostawał zazwyczaj jeden z zamożniejszych i najbardziej szanowanych szlachciców w zaścianku, cieszący się autorytetem i poważaniem.

Każda gmina posiadała okrągłą pieczęć, zawierającą oprócz nazwy miejscowości także herb szlachecki. Na przykład pieczęć gminy baczyńskiej była wielkości półtalara. Na środku znajdował się napis „GBHS” - czyli Gmina Baczyna Herbu Sas zwieńczony u dołu liściem wawrzynowym. Cała pieczęć ozdobiona została koroną szlachecką o pięciu perłach i dwoma krótkimi pałaszami, umieszczonymi na obydwu rogach korony. Antoni Schneider, lwowski archiwista i twórca przebogatej kolekcji archiwalnych dokumentów dotyczących życia społecznego Galicjiiº, pisał, że pieczęć gminy szlacheckiej

przekonuje nas jak najwyraźniej o pochodzeniu i dawnym znaczeniu gminy [...]. Jest to [Baczyna - K.Ś.] jedna z tych tak licznych osad na Pogórzu Karpackim, które osiedlone po większej części jeszcze za czasów książąt ruskich, później za rządów polskich, a następnie za c.k. rządów austriackich, aż do najnowszych czasów doznawały szlacheckiego zaszczytu, pomimo że ich stan majątkowy i dawne pożycie stawiały po większej części na równi z innymi włościanami w okolicy, lub mało co ich w tychże odróżniały ${ }^{31}$.

Gmina szlachecka spełniała w życiu szlachty zaściankowej bardzo ważną rolę. $Z$ jednej strony podkreślała odrębność od ludności chłopskiej, z drugiej zaś - przynależność do uprzywilejowanego stanu szlacheckiego. Drobna szlachta starała się więc jak najdłużej zachować tę instytucję. Niestety, już po wprowadzeniu autonomii Galicji, gminy szlacheckie zostały zniesione. Ustawa z 1866 roku stworzyła bowiem jedną gminę wiejską, w obrębie której miała się znaleźć także i szlachta zaściankowa. To unormowanie zostało odczytane jako posunięcie krzywdzące, odbierające szlachcie zagrodowej jedną z ostatnich prerogatyw, i stało się powodem rozlicznych protestów. Nie wpłynęły one jednak na stanowisko władz autonomicznych, gdyż ostatecznie

29 Rolę taką spełniał m.in. prefekt gminy szlacheckiej w Berezowie Niżnym i Wyżnym. Zob. ANK, TS 80. Takie funkcje gminy szlacheckiej zdają się potwierdzać również źródła literackie. Zob. A. Чайко в ський, Олюнька. Повісті та оповідання, Львів 1966, s. 78-80.

30 Chodzi o Teki Antoniego Schneidra przechowywane w Archiwum Narodowym w Krakowie oraz w Lwowskiej Naukowej Narodowej Bibliotece im. W. Stefanyka.

31 ANK, Teki Schneidra, sygn. 28, nlb. 
w 1870 roku namiestnictwo nakazało włączyć faktycznie istniejące gminy szlacheckie do gmin wiejskich ${ }^{32}$.

Niebagatelne znaczenie w kultywowaniu tradycji szlacheckich miał sam herb. Stare dokumenty, nadania królewskie, certyfikaty szlachectwa przechowywano jak największą świętość. Szlachcic zagrodowy mógł mieszkać w kurnej chacie z klepiskiem zamiast podłogi, cierpieć wszelkie niewygody, ale dumny był z tego, że posiadał klejnot, który choć nie błyszczał, to zawsze przypominał o dawnej świetności. Bogusław Longschamps de Berier, opisujący w swoich wspomnieniach zaścianek we wsi Żupań, odnotował: „W Żupaniu siedzieli sami Turzańscy. Chłopy wielkie jak jodły i buki, o rękach jak maczugi, pozornie powolni i ociężali. Razem z »przywilejami«, schowanymi jak największy skarb na dnie skrzyni, przechowywali polską wiarę i mowę, i miłość ojczyzny"33. Podobne odczucia miał Antoni Schneider, który w swoich notatkach na temat zaścianka w Baczynie zaznaczył: „Nieraz człowiek prosty do herbu przyjęty, nawet nazwiska klejnotu swego nazwać nie umiał, ale mimo to pysznił się z niego, wiedząc o tem, że będąc ozdobiony herbem, został synem koronnym" 34 .

W świadomości szlachty zagrodowej i czynszowej herb odgrywał rolę jednego z najważniejszych elementów pozwalających odróżnić się od chłopów. Biedni szaraczkowie gospodarujący na kilkumorgowych zagonach, własnych lub dzierżawionych, nie mieli bowiem innego sposobu na zamanifestowanie swej przynależności do stanu szlacheckiego. Przechowywanie dokumentów poświadczających herb, a nawet samo wspomnienie o nim, przypięcie do pasa choćby nawet kija przypominało chłopskiemu otoczeniu, że ma do czynienia ze szlachtą. Już w XX wieku fakt ten bardzo wyraźnie podkreślał Ferdynand Ossendowski, który pisał, że chociaż już pod koniec XVIII wieku ,ten i ów z Ilnickich, Matkowskich, czy Wysoczańskich - pracując przy pługu, kroczył po bruździe bosy i o szlacheckim jego prawie, krwi i honorze świadczył kord - na pasie rzemiennym wiszący"35.

Przynależność drobnej szlachty do stanu uprzywilejowanego była podkreślana także w zwyczajowej tytulaturze. Pod koniec XVIII i jeszcze w pierwszych dekadach XIX wieku w różnych aktach prywatnych i dokumentacji urzędowej dość powszechnie stosowano tytuły generosus, nobilis czy „urodzony”. W okresie późniejszym zwyczaj ten zanikł, ale w dokumentach urzędowych powszechnie stosowano zwroty Edler lub Ritter, oznaczające stopnie szlachectwa w austriackim systemie prawnym. Rzecz jasna, te ostatnie określenia stosowano jedynie w odniesieniu do osób wylegitymowanych ze szlachectwa. Okazuje się jednak, że i w wypadku szlachty niewylegitymowanej, której wcale nie było tak mało, stosowano różne zwroty i określenia podkreślające jej przynależność do warstwy uprzywilejowanej. $\mathrm{Na}$ przykład w inwentarzach gruntowych szlachtę czynszową wyróżniano następująco:

32 K. Grzybowski, Galicja 1848-1914. Historia ustroju politycznego na tle historii ustroju Austrii, Kraków-Wrocław-Warszawa 1959, s. 276.

33 B. Longchamps de Berier, Ochrzczony na szablach powstańczych... Wspomnienia (18841918), Wrocław 1983, s. 221.

${ }^{34}$ ANK, Teki Schneidra, sygn. 28, nlb.

35 F. Ossendow ski, Karpaty i Podkarpcie, Poznań 1938, s. 250. 
„panowie szlachta, którzy temi czasy już czynsz gotowemi pieniędzmi płacą” lub „panowie szlachta chałupnicy”36. Ten ostatni zwrot zasługuje na szczególną uwagę. Mamy tu bowiem do czynienia z niezwykłym połączeniem dwóch, przeciwstawnych przecież światów: szlacheckiego - „panowie szlachta” i chłopskiego - „, chałupnicy”.

Podkreślanie na każdym kroku przynależności do stanu szlacheckiego, tak częste w życiu zdeklasowanej szlachty, stanowiło także formę obrony przed wtopieniem się w ludność chłopską. Przecież zubożała szlachta wolna, do której należały „fortuny" o powierzchni mniejszej niż jedna morga, lub szlachta czynszowa, uprawiająca ziemię odpowiadającą wielkością gospodarstwom kmiecym, zagrodniczym czy chałupniczym, w sensie materialnym niczym nie różniła się od chłopów. Mało tego, była od nich uboższa. Zrównanie w prawach $\mathrm{z}$ chłopami, co dokonało się $\mathrm{w}$ drugiej połowie XVIII i pierwszej połowie XIX wieku, oznaczało faktyczną deklasację. Środowiska najbardziej zagrożone wypchnięciem poza granice stanu podjęły więc walkę w obronie dotychczasowej pozycji. Polegała ona na zdecydowanym odcięciu się od ludności chłopskiej. Przejawiało się to głównie kultywowaniem przeszłości, ciągłym odwoływaniem się do szlacheckiego rodowodu, odrębnym ubiorem i sposobem bycia. Absolutnie niedopuszczalne było również zawieranie związków małżeńskich z chłopkami. Postawy takie dało się zauważyć już w drugiej połowie XIX wieku. Autor notki zamieszczonej w Słowniku geograficznym Królestwa Polskiego i innych krajów stowiańskich tak charakteryzował szlachtę mieszkającą w Komarnikach w Samborszczyźnie:

Szlachcic mówi do chłopa, choć starszego wiekiem i majętniejszego „ty”, a chłop choć zamożny, mówi do szlachcica „wy”. Chłopi wołają swe dzieci niezmiennymi imionami chrzestnymi, np. Iwan, Wasyl, Ałeksandr, Teodor (albo Fedor) itd.; szlachta, przeciwnie, chcąc się odróżnić od chłopów, zmienia te imiona na Jasio, Wasio, Fedio, Łesio itd. Chłop jest skłonniejszy do pijaństwa aniżeli szlachcic, chłopianki mniej dbają o cześć niż szlachcianki. Za to znowu chłopi pracowitsi, solidniejsi i zgodniejsi. Zdarza się niekiedy, że w jednej chacie mieszkają dwie, trzy, albo i cztery rodziny, i nie toczą z sobą sporów; u szlachty zaś żonaty syn nie może mieszkać wraz z ojcem i przez rok jeden. Chłop jest niedowierzający, podejrzliwy, ale otwarty; szlachcic słodki w oczy, ale przy tem podstępny, samolubny, chciwy honorów, do procesów bardzo pochopny. Antagonizm między szlachtą a chłopami znaczny; najwybitniej okazuje się on wówczas, gdy chłopianka idzie za szlachcica, lub szlachcianka za chłopa, co się jednak rzadko kiedy zdarza ${ }^{37}$.

Podobne cechy zauważył również Andrij Czajkowśkyj, ukraiński prawnik, polityk i pisarz, który wychowywał się w zaścianku w Hordyni w Samborszczyźnie. W swoich opowiadaniach zwracał on uwagę między innymi na różnice w ubiorze. Szlachcic nosił surdut (choćby płócienny), kaszkiet, czyli czapkę z daszkiem (,rogatywka kroju Kilińskiego"), zimą - niską baranicę, szytą na wzór niemieckich sztyftów. Chłop natomiast ubierał się w kaftan z płótna „słowiańskiego kroju” i szerokie spodnie, szyte na kozacki sposób ${ }^{38}$.

36 ANK, Teki Schneidra, sygn. 1166, nlb.

37 Słownik geograficzny Królestwa Polskiego i innych krajów słowiańskich, t. 4, red. F. Sulimierski, B. Chlebowski, W. Walewski, Warszawa 1883, s. 229-301.

38 А. Чайковський, op. cit., s. 78-79. 
Podkreślanie własnej odrębności i manifestowanie uprzywilejowanej pozycji społecznej bardzo często przeradzały się w wyraźną niechęć, a nawet wrogość w stosunku do chłopów. Antoni Schneider tak opisywał stosunek szlachty z Ladzkiego Szlacheckiego na Pokuciu do miejscowych chłopów:

Uznaje szlachta włościanina za stworzenie niższe i strzeże święcie ten stosunek wyjątkowy swawolą, butą wszelkiego rodzaju. Unika też wszelkiego związku z włościanami. Z przeciwnej strony żyje włościanin od dawna w nieprzełamanej nieprzychylności i odrazie ku tej szlachcie. I nie może pomieścić w swojej głowie, jakim prawem ten sam, czasem obdarty [szlachcic K.Ś.], któren o jedną staję od niego [razem] z nim chudobę pasie, może tak zawzięcie domagać się tytułu pana. I nie może temu szczęśliwemu ani oświatą, ani majątkiem lepszym dorównać; za wybryki, zuchwałości i za osobliwe położenie szlachcica; że się nie czuje żadnymi prawami ściśnięty, ino wszędzie wyłamy [tu: przewinienia - K.Ś.] bezkarnie mu uchodząą

$* * *$

Zmieniające się w ciągu XIX stulecia położenie galicyjskiej drobnej szlachty można porównać z balansowaniem na linie. Postępujące ubożenie i utrata przywilejów (w następstwie przemian politycznych i ustrojowych dokonujących się w monarchii habsburskiej) powodowały, że szlachecki drobiazg był wypychany poza granice stanu szlacheckiego. W praktyce prowadziło to do faktycznego upodobnienia się (w sensie materialnym i prawnym) części szlacheckiej braci do ludności chłopskiej. Mając świadomość zagrożenia, drobna szlachta podjęła kroki zaradcze, ale siłą rzeczy mogły one polegać jedynie na odróżnieniu się od chłopów poprzez kultywowanie tradycji i zwyczajów szlacheckich.

W tym miejscu trzeba zadać pytanie: czy owa próba trwania w tradycji szlacheckiej oraz zachowania własnej tożsamości społecznej była udana? Odpowiedź nie jest łatwa i zależy od tego, o jakim czasie mówimy. Na pewno w drugiej połowie XIX wieku poczucie szlacheckiej tożsamości było bardzo silne (świadczą o tym choćby przytaczane wyżej opinie). W XX wieku, a zwłaszcza w okresie dwudziestolecia międzywojennego, pełną świadomość przynależności do stanu szlacheckiego miała zapewne część potomków szlachty zagrodowej ${ }^{40}$. Znamy bowiem relacje, z których wynika, że podobnie jak pod koniec XIX stulecia w różnych schowkach przechowywano dokumenty poświadczające szlachectwo. Na przykład wywodzący się z Ladzkiego Szlacheckiego Roman Zuber, wspominając swoje dzieciństwo, opisał taką oto historię:

Około 1937 r. przypadkowo odkryłem dokumenty świadczące o przynależności rodu Zubrów do szlachty herbowej i o tym fakcie poinformowałem mojego brata Eustachego. W pokoju naszego nowego domu był duży stół tak skonstruowany, że pod jego blatem znajdowała się płaska skrzynia, do której wsunięta była duża szuflada. Po obu stronach szuflady znajdowały

39 ANK, Teki Schneidra, sygn. 888, nlb.

40 Tę świadomość dodatkowo wzmacniała działalność polskich władz, które w latach 30. XX w. podjęły akcję repolonizacji drobnej szlachty kresowej. Więcej na ten temat zob. M. Kacprzak, Towarzystwo Rozwoju Ziem Wschodnich 1933-1939, Łódź 2005. 
się wnęki dostępne dopiero po całkowitym jej wyciągnięciu. Był to tajemniczy schowek, o którym na pewno wiedział mój ojciec Jan, dziadek Andrzej i zapewne pradziadek, którego imienia wtedy jeszcze nie znałem. W tym tajemniczym schowku znajdowało się bardzo dużo różnych dokumentów związanych z naszą rodziną [...]. W schowku znajdowały się również dokumenty pisane ozdobnym pismem łacińskim na pergaminie. Pamiętam, że w tych dokumentach, pochodzących z XVIII w., Stacho odczytywał niektóre fragmenty. Mój brat, znający łacinę, próbował treść dokumentów rozszyfrować, ale to wymagało dokładniejszych studiów. Powiedział, że wypożyczy jakiś porządny słownik łacińsko-polski i spróbuje je przetłumaczyć. Był przekonany, że są to dokumenty potwierdzające przynależność naszej rodziny do szlachty. Niestety, obydwaj nie przywiązywaliśmy do tych dokumentów zbyt dużej wagi i nie przetłumaczyliśmy ich na język polski ${ }^{41}$.

Czy jednak posiadanie szlacheckiego rodowodu i przechowywanie poświadczających ten fakt dokumentów miało jakiś praktyczny walor? Czy potomkowie szlachty zaściankowej starali się odróżnić od sąsiadów o chłopskim pochodzeniu? Odpowiedź na te pytania jest raczej negatywna. W tym czasie przynależność do stanu szlacheckiego miała znaczenie czysto symboliczne i w codziennym życiu nie odgrywała większej roli.

\section{BIBLIOGRAFIA}

\section{I. Źródła}

\section{1. Źródła archiwalne}

Archiwum Narodowe w Krakowie:

Teki Schneidra:

sygn. 28, 80, 682, 888, 1038, 1071, 1166, 1449, 1608, 1800-1858.

Львівська національна наукова бібліотека України імені В. Стефаника:

Zbiór Czołowskiego:

sygn. 941/III.

Центральний державний історичний архів України - м. Львів (ЦДІАУЛ)

ф. 146: Namiestnictwo Galicyjskie:

оп. 85, спр. 2780 ,

оп. 87, спр. 206.

ф. 149: Forum Nobilium we Lwowie:

оп. 4, спр. 2327, 2328, 2329.

41 R. Zuber, Dzieje rodu Zubrów. Wspomnienia z Olch, Szlacheckiego Kąta, Pacykowa i Kotuzowa, do dr. przyg., przedm. i przyp. K. Ślusarek, Kraków 2012, s. 13-14. 


\section{2. Źródła drukowane}

Longchamps de Berier B., Ochrzczony na szablach powstańczych... Wspomnienia (1884-1918), Wrocław 1983.

Zuber R., Dzieje rodu Zubrów. Wspomnienia z Olch, Szlacheckiego Kąta, Pacykowa i Kotuzowa, do dr. przyg., przedm. i przyp. K. Ślus arek, Kraków 2012.

Чайковський А., Олюнька. Повісті та оповідання, Львів 1966.

\section{Opracowania}

Dąbkowski P., Szlachta zaściankowa w Korczynie i Kruszelnicy nad Stryjem, Lwów 1936.

Grzybowski K., Galicja 1848-1914. Historia ustroju politycznego na tle historii ustroju Austrii, Kraków-Wrocław-Warszawa 1959.

Jewuła Ł., Kargol T., Ślus arek K., Dwór, wieś i plebania w przestrzeni społecznej zachodniej Małopolski w latach 1772-1815, Kraków 2015.

Kacprzak M., Towarzystwo Rozwoju Ziem Wschodnich 1933-1939, Łódź 2005.

Ossendowski F., Karpaty i Podkarpacie, Poznań 1938.

Słownik geograficzny Królestwa Polskiego i innych krajów słowiańskich, t. 4, red. F. Sulimierski, B. Chlebowski, W. Walewski, Warszawa 1883.

Ślusarek K., Austria wobec polskiej szlachty z Galicji w latach 1772-1861, „Studia Historyczne" 2012, t. 55, z. 2, s. 185-200.

Ślusarek K., Bilina Wielka, Kraków 2010.

Ślusarek K., Drobna szlachta w Galicji 1772-1848, wyd. 2, Jędrzejów-Kraków 2011.

Ślusarek K., Drobna szlachta w Obertynie. Studium z dziejów szlachty w matym miasteczku na przełomie XVIII i XIX wieku, „Studia Historyczne” 1994, t. 37, z. 3, s. 359-374.

Wyrostek L., Ród Dragów-Sasów na Węgrzech i Rusi Halickiej, „Roczniki Towarzystwa Heraldycznego" 1931-1932, t. 11, s. 1-152.

Історія села Кульчищь і роду Драго-Сасів, ред. Я. Радевич-Винницький, [Львів] 1995.

Лаба В., Історія села Ільник від найдавніших часів до 1939 року, Львів 2009.

Сородник С., Історія корчинської иляхти. Минуле і сучасне села Корчин, Львів 2002. 